\title{
The Effectiveness of Using the Zondaag Maandag Traditional Sports Game Model to Improve Learning Outcomes of Basic Motion for Children aged 10-12 Years
}

\author{
Abdul Hakim Siregar \\ Lecturer in PJKR Program of Physical Education, Universitas Negeri Medan, Indonesia \\ abdhakim@unimed.ac.id
}

\begin{abstract}
This study aims to see the effectiveness of using the traditional zondaag mandaag sports game model in improving the basic motion learning outcomes of children aged 10-12 years. The research method used to test the effectiveness with a quantitative descriptive approach using the True Experimental Design research design in the form of a Pretest-Postest Control Group Design. The research sample used was 60 students who were divided into 30 students of experimental class and 30 students of control class with a closed questionnaire instrument using a Likert scale of movement skills test adopted from the Test of Gross Motor Development. The results showed that the test data obtained Equal variances assumed and t-test for Equality of Means with a value of $t=$ 17.877, $d f=58(n-2)$ and sig ( 2 tailed) or p-value $=0.000<0.05$ or $\mathrm{HO}$ was rejected. Thus the hypothesis proposed is tested by the data so that it can be concluded that the results of learning the basic motion of the experimental group using the traditional zondaag mandaag sports game model are higher or more effective than the control group using conventional learning models.
\end{abstract}

Keywords

basic movement; learning outcomes, traditional sports games

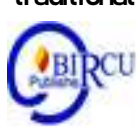

\section{Introduction}

Education that is carried out from time to time is always changing in accordance with the times. Therefore, teachers as learning managers are required to be more creative and innovative in order to make learning outcomes more optimal. This is in accordance with the Law of the Republic of Indonesia Number 20 of 2003, Article 1 paragraph 19, concerning the National Education System (Sisdiknas) that education is a conscious and planned effort to realize a learning atmosphere and learning process so that students actively develop their potential to have spiritual, religious, self-control, personality, intelligence, noble character, and skills needed by themselves, society, nation and state. (Simorangkir and Sembiring, 2018)

The learning model can be interpreted as a plan or pattern used in compiling the kirikulum, arranging learning material and giving instructions to the teacher in the learning process. Elias M. Award \& Hassan M Ghaziri (2010) stated that "A models is a representation of real of planned system." The purpose of this statement is a model as a representation of a planned system reality. Project based learning is supported by constructivist learning theory. Constructivism is a learning theory that has broad support that relies on the idea that students build their knowledge in the context of their own experiences. (Piliang and Asnewastri, 2020) 
Games are a form of activity in physical education. According to Werner, Thorpe, \& Bunker, (1996) Games are an important component of the Physical Education curriculum (Rahman et al., 2020). In essence, playing for early childhood is a learning process, for that we need media that is able to stimulate children's development through various traditional games (Yani, 2015).

The traditional sports game zondaag mandaag is a folk game which is still often played in the Mandailing tribe. This game with various names that spread to all corners of the archipelago. The hallmark of this game is jumping on one foot in the box. The mandaag zondaag game is very easy. It only takes chalk or rock rubble to draw a zondaag mandaag map on a cement or dirt floor. The tools that are plastered usually use kereweng (ceramic broken). This game has many rules, one of which is that the feet must not come out of the box, when throwing the dwarf you cannot get out of the box and so on.

Physical education, sports and health are among the subjects in elementary schools. Physical education and sports can be defined as an educational process through selected physical activities, games and sports to achieve educational goals (H.K. Manners and M.E. Carroll, 2004). Furthermore, Sallis et al. in (Egan et al., 2019) stated that "Physical education (PE) is considered essential for helping children to develop the knowledge, skills, and dispositions they need to build a physically active life. This means that physical education is important to help children develop the knowledge, skills, and dispositions they need to build a physically active life.

One type of physical education learning material in grades 4-6 SD is basic motion learning (locomotor, non-locomotor and manipulative). Basic motor skills (KMD) are gross movement skills that children acquire and develop as they age, and form the foundation for more advanced motion and specific movement patterns (Gabbard, 2012). This is also reinforced by (Nazario \& Vieira., 2013) and (Rodrigues et al., 2015) in their research that the ability to move requires full development in all periods in such a way that previous experiences become the basis for experiences and development in subsequent periods.

Researchers from abroad also argue that developing basic movement skills since pre-school provides children with the tools needed to be physically active, especially when they start school and there is a positive relationship between basic movement skills and physical activity (Figueroa \& An, 2016) and (Klingberg) et al., 2018). In Indonesia, almost all existing primary schools carry out this activity, with the reason that each school can implement these basic movement skills. Time and place does not cost a lot, and in the curriculum of physical education, sports and health, this basic movement is one of the materials learned in elementary school grades 4-6 SD. According to student characteristics According to David L. Gallahue, (2006) is the Conventional Chronological Classifications of Age, which in this theory is written specifically for elementary school age that the classification of developmental stages is as follows, in the 2-7 year age period it is a fundamental phase of movement phase (basic movement stage) and in the period of 7 years-10 years, 11 years-13 years, 14 years is a specialized movement phase.

However, based on observations made by researchers in the implementation of physical education, sports and health learning by applying a learning model, there are still deficiencies and need for improvement, especially in basic motion learning (locomotor, non-locomotor and manipulative) the presentation is not accompanied by a clear learning implementation design, such as the learning materials to be provided, time allocation, and good classroom management. The very real impacts are seen, among others: (1) lack of teacher approach to students in the learning process, (2) lack of evaluation of learning outcomes towards students at the end of the activity, (3) lack of clarity on targets to be achieved in the learning process (4) lack of understanding teachers in the method or approach that will be used in delivering learning material. (5) The teacher's inability to create a good and innovative learning model. 
The deficiencies in the physical education, sports and health learning process, which were stated earlier, certainly have a negative impact on students. This is reinforced by one study which states that the pattern of physical activity in children has a tendency to be lower and of course will cause a big impact (Kain et al., 2009) and (Tucker, 2008). Meanwhile, research related to motor skills in early childhood has been carried out by various researchers both in Indonesia and abroad. (Monsalves-alvarez et al., 2015) in their study also linked motor skills and nutritional status resulting from physical activity interventions on short breaks in preschool children carried out by their teachers. In conclusion, they said that the role of the family and the playground teacher is very important, to achieve these recommendations and to motivate children "daily activities" to ensure and facilitate physical play, which will result in adequate fitness as well as optimal growth and health. (Lin \& Yang, 2015) in their study looked at the development of basic movement skills by children aged six to nine years and explained the differences that may exist in the basic movement skills of children in Chiayi City and Chiayi County. They also suggest that schools need to provide a variety of movement activities that are carried out by students and are attractive to those students, and also encourage students to participate in sports after class and outside of school. This research is important to carry out because based on observations made by the author, learning PJOK, especially basic movements, still has several weaknesses so that it needs to be developed.

From the results of the problem background and theoretical study, the authors examined the extent to which the effective use of the traditional zondaag mandaag sports game model to improve learning outcomes of basic motion (locomotor, non-locomotor and manipulative) children aged 10-12 years.

\section{Research Methods}

The research method used to test the effectiveness with a quantitative descriptive approach using the True Experimental Design research design in the form of a Pretest-Postest Control Group Design (Sugiyono, 2017). The research population was SD Negeri 064970 which was selected as a sample of 60 children, consisting of 30 children aged 10-12 years in the control group and 30 children aged 10-12 years in the experimental class with a closed questionnaire instrument using the Likert scale of the movement skills test. adopted from the Test Of Gross Motor Development. In this design, there are two groups selected randomly, then given a pretest to determine the initial state whether there is a difference between the experimental group and the control group. The pretest results are good if the experimental group scores are not significantly different. The effect of the treatment is (O1 - O2) - (O4 O3) which analyzed the results of the pre-test and post-test using statistical methods (t-test) and the gain score using the IBM SPSS 25 application.

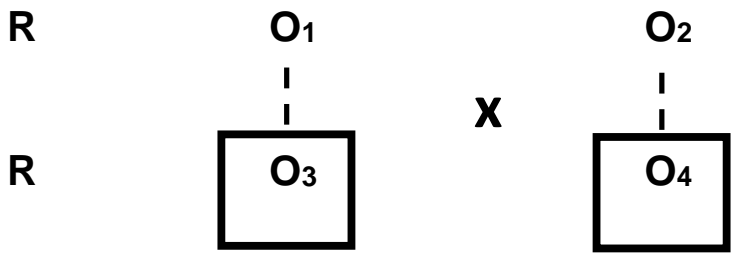

Figure 1. Experimental Design with a control group (Pretest-Posttest Control Group Design)

Source: (Sugiyono, 2019) 
Information:

$\mathrm{R}$ : Control group or experimental group

O1: The initial ability value of the experimental group

O2: The performance of the experimental group with the new system / performance / model

O3: The initial ability value of the control group

O4: The performance of the experimental group with the old system / performance / model

The research hypothesis on the effectiveness of this model is that it is suspected that there is a significant influence between the traditional zondaag mandaag sports game model against the conventional model for improving basic motion learning outcomes in children aged 10-12 years. The steps taken in this study include: (1) determining the research subject group; (2) carry out the pre-test $(\mathrm{O} 1)$; (3) provide a traditional sports game model Zondaag Mandaag; (4) carrying out the post-test (O2); (5) looking for pre-test and post-test mean scores and comparing them; (6) find the difference between the two means through statistical methods (t-test) to determine whether there is a significant effect of using the model. The formula for processing the data as a whole the test subjects used the t-test procedure and calculations using the gain score in each group to determine the amount of increase that occurred in each research subject using the IMB SPSS application.

$$
t=\frac{\bar{X}_{1}-\bar{X}_{2}}{\sqrt{\frac{s_{1}^{2}}{n_{1}}+\frac{s_{2}{ }^{2}}{n_{2}}-2 r\left[\frac{s_{1}}{\sqrt{n_{1}}}\right]\left[\frac{s_{2}}{\sqrt{n_{2}}}\right]}}
$$

Information:

$\overline{X_{1}}:$ Average $\mathrm{X} 1$

$\overline{X_{2}}:$ Average X2

S1: Standard Deviation 1

S2: Standard Deviation 2

S12: Variance 1

S22: Variance 2

r: Correlation between two groups

\section{Result and Discussion}

Data from the analysis of the effectiveness of the traditional zondaag mandaag sports game model to improve learning outcomes for children aged 10-12 years using the t-test procedure assisted by the IBM SPSS 25 software. Before analyzing the data, the data obtained must meet one of the prerequisite tests for analysis, namely the normality test. for the experimental class and control class data on basic motion learning outcomes using the Kolmogorov-Smirnov test at a significant level $\alpha=0.05$. The following are the test results in the experimental group and the control group: 


\subsection{Experiment Group}

Table 1. Descriptive Statistics of Pretest \& Posttest Result Experiment Group

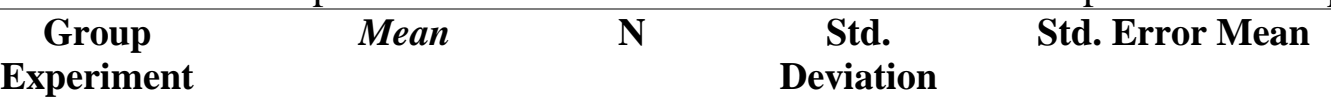

\begin{tabular}{ccccc} 
Pre-test & 164,10 & 30 & 3,367 & 0,615 \\
\hline Post-test & 172,73 & 30 & 5,558 & 1,015
\end{tabular}

In table 1 the average learning outcomes of the basic movement skills test with a sample of 30 students obtained that the pretest had a mean of 164.10 and a standard deviation of 3.36. After being given the treatment of the traditional zondaag mandaag sports game model, the post test results have a mean of 172.73 and a standard deviation of 5.55. This means that quantitatively there are differences in the average learning outcomes of the basic movement skills test before and after treatment is given.

Table 2. Paired Samples Correlation Experiment Group

\begin{tabular}{ccccc}
\hline \multicolumn{5}{c}{ Paired Samples Correlations } \\
\hline & $\mathrm{N}$ & Correlation & Sig. \\
\hline Pair 1 & Post Test \& Pre Test & 30 & 0,593 & 0,001 \\
\hline
\end{tabular}

Based on the table 2 paired samples correlation, the correlation coefficient of the test scores for the results of learning the basic motion between before (pre test) and after (post test) was given treatment in the form of a traditional zondaag mandaag sports game model of 0.593 with a Sig or $\mathrm{p}$-value $=0.001<0.05$. or significant.

Table 3. Results of the Paired Sample Test for the Experimental Group

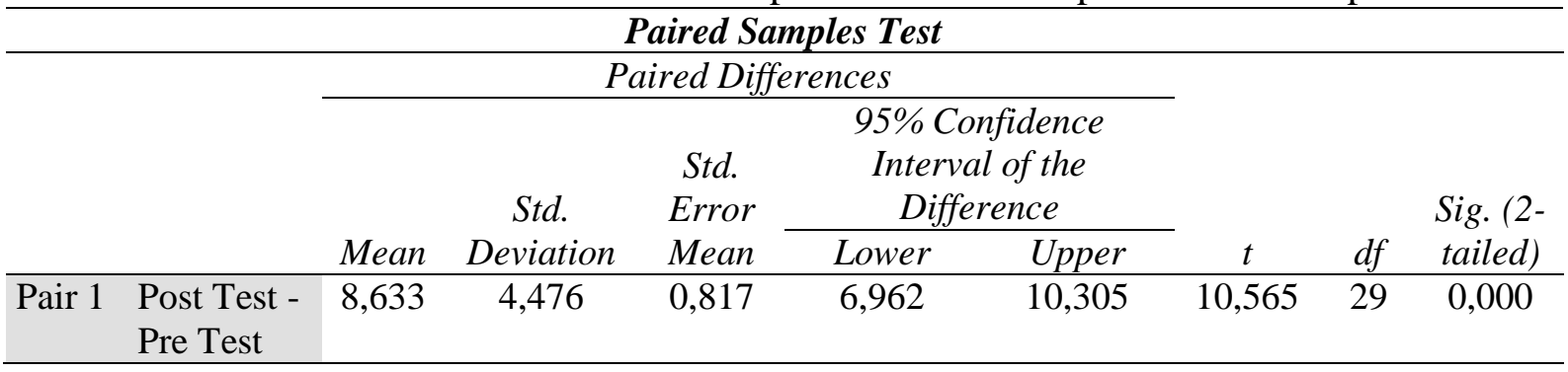

Based on table 3 of the results of the paired samples test, the mean difference is that the difference in the results of learning basic motion is 8.63. Based on the table above, it is found that the price of $\mathrm{t}$ count $=10.565$ for $=0.05$ and $\mathrm{t}$ table $=2.045$, it turns out that $\mathrm{t}$ count $>\mathrm{t}$ table, namely 10.565> 2.045 and the sig or p-value $=0.000>0.05$ with $\mathrm{df}=29$. Thus, H0 rejected and $\mathrm{H} 1$ accepted, which means that there is a significant difference in the mean before (pretest) and after (posttest) given (treatment) the traditional Zondaag Mandaag sports game model.

\subsection{Control Group}

The activity carried out in the control group was to apply a model commonly used by field teachers in the school, namely by using a basic motion model derived from student sports books termed conventional models. In the control class the treatment time and number of samples remained the same. From the results of the control class research, it was obtained that the pretest and posttest results were as follows: 
Table 4. Paired Samples Statistics Pretest \& Posttest Control Group Test

\begin{tabular}{|c|c|c|c|c|}
\hline $\begin{array}{c}\text { Group } \\
\text { Control }\end{array}$ & Mean & N & $\begin{array}{c}\text { Std. } \\
\text { Deviation }\end{array}$ & Std. Error Mean \\
\hline Pre-test & 141,03 & 30 & 11,038 & 2,015 \\
\hline Post-test & 145,37 & 30 & 6,278 & 1,146 \\
\hline
\end{tabular}

Based on table 4 with a sample size of 30 people, the mean pre test results are 141.03 and a standard deviation of 11.038. After being given the conventional basic motion learning model, the mean post test results are 145.37 and the standard deviation is 6.278 . This means that quantitatively in Table 4, there is a difference in the results of the pre-test and post-test before and after being given treatment using a conventional model. To find out the correlation between the results of the pre-test and post-test in the control group, the paired samples correlation test was carried out as follows:

Table 5. Paired Samples Correlations Test for Pretest \& Posttest Control Group

\begin{tabular}{lcccc}
\hline \multicolumn{5}{c}{ Paired Samples Correlations } \\
\hline & $\mathrm{N}$ & Correlation & Sig. \\
\hline Pair 1 & Post Test \& Pre Test & 30 & 0,609 & 0,000 \\
\hline
\end{tabular}

Based on table 5, it is obtained that the correlation coefficient of the score of basic motion learning outcomes between before (pre test) and after being given treatment (post test) of the conventional basic motion learning model is 0.609 with the sig or p-value $=0.000$ $<0.05$ significance. Knowing the significance results between the pre-test and post-test, the pretest and posttest paired samples test was conducted in table 5 below:

Table 6. Paired Samples Test Pretest Posttest Control Group Test

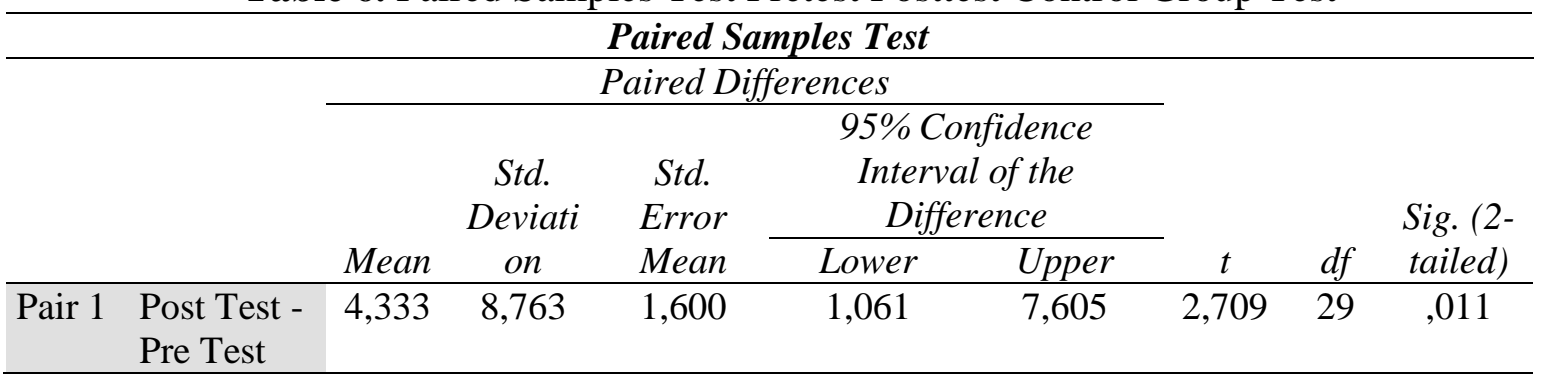

Based on table 6, the results of the paired samples test, the mean difference is obtained, namely the difference in the results of learning basic motion learning outcomes of 4.333 . Based on the table above, it is found that the price of tcount $=2.709$ for $=0.05$ and table $=$ 2.045 , it turns out that tcount $>$ ttable, which is $10,565>2,045$ and the sig or p-value $=0,000>$ 0.05 with $\mathrm{df}=29$. Thus, $\mathrm{H} 0$ rejected and $\mathrm{H} 1$ accepted, which means that there is a significant difference in the mean before (pretest) and after (posttest) given (treatment) the conventional basic motion learning model.

Before carrying out the t-test, the researcher must test the prerequisite analysis, namely the normality test. The following is a summary of the results of the calculation of the normality test shown in table 7. 
Table 7. Summary of Data Normality Test Calculation Results for the Experiment Group and Control Group on Basic Motion Learning Outcomes

\begin{tabular}{|c|c|c|c|c|c|c|c|}
\hline \multicolumn{8}{|c|}{ Tests of Normality } \\
\hline & \multirow[b]{2}{*}{ Group } & \multicolumn{3}{|c|}{ Kolmogorov-Smirnov ${ }^{\mathrm{a}}$} & \multicolumn{3}{|c|}{ Shapiro-Wilk } \\
\hline & & Statistic & $\mathrm{df}$ & Sig. & Statistic & $\mathrm{df}$ & Sig. \\
\hline $\begin{array}{l}\text { Hasil } \\
\text { Belajar }\end{array}$ & $\begin{array}{l}\text { Experiment } \\
\text { Group }\end{array}$ & 0,157 & 30 & 0,058 & ,949 & 30 & 0,157 \\
\hline $\begin{array}{l}\text { Basic } \\
\text { Motion }\end{array}$ & $\begin{array}{l}\text { Control } \\
\text { Group }\end{array}$ & 0,148 & 30 & 0,092 & ,932 & 30 & 0,055 \\
\hline
\end{tabular}

Based on table 7 the test results can be seen in the Kolmogorov-Smirnov column, it is known that the sig value for the experimental group data is 0.058 and the control group data is 0.092 . The results of the sig value of the two groups $>\alpha(0.05)$, it can be concluded that the overall data of the research group is normally distributed. After fulfilling the prerequisite analysis test, namely the normality test, the effectiveness test of the application of the Zondaag Mandaag traditional sports game model uses the "t-test" which is summarized in table 8 below:

Table 8. Test the Effectiveness of a Traditional Sports Game Model Using the T Test

\begin{tabular}{|c|c|c|c|c|c|c|c|c|c|c|}
\hline \multicolumn{11}{|c|}{ Independent Samples Test } \\
\hline & & $\begin{array}{l}\text { Leven } \\
\text { for Equ } \\
\text { Vari }\end{array}$ & $\begin{array}{l}\text { s Test } \\
\text { lity of } \\
\text { nces }\end{array}$ & & & $\mathrm{t}$-test $\mathrm{f}$ & for Equality & of Means & & \\
\hline & & \multirow[b]{2}{*}{$\mathrm{F}$} & \multirow[b]{2}{*}{ Sig. } & \multirow[b]{2}{*}{$\mathrm{T}$} & \multirow[b]{2}{*}{ Df } & Sig. (2- & Mean & Std. Error & $\begin{array}{r}95 \% \text { Co } \\
\text { Interva } \\
\text { Diffe }\end{array}$ & $\begin{array}{l}\text { fidence } \\
\text { of the } \\
\text { ence }\end{array}$ \\
\hline & & & & & & tailed) & Difference & Difference & Lower & Upper \\
\hline $\begin{array}{l}\text { Basic } \\
\text { Motion } \\
\text { Learning }\end{array}$ & $\begin{array}{l}\text { Equal } \\
\text { variances } \\
\text { assumed }\end{array}$ & 0,030 & 0,864 & 17,877 & 58 & 0,000 & 27,367 & 1,531 & 24,302 & 30,431 \\
\hline Outcomes & $\begin{array}{l}\text { Equal } \\
\text { variances } \\
\text { not } \\
\text { assumed }\end{array}$ & & & 17,877 & 7,160 & 0,000 & 27,367 & 1,531 & 24,301 & 30,432 \\
\hline
\end{tabular}

Based on the table above 8. in the Equal variances assumed and Levene's Test for Equality of Variances column, the value of $\mathrm{F}=0.030$ is obtained with a sig or $\mathrm{p}$-value $=$ $0.864>0.05$, which means that the population variances of the two groups are the same or homogeneous and meet the requirements for hypothesis testing. The results of hypothesis testing can be seen in the Equal variances assumed and t-test for Equality of Means column. From this column, the value of $\mathrm{t}=17.877, \mathrm{df}=58(\mathrm{n}-2)$ and sig ( 2 tailed) or $\mathrm{p}$-value $=0.000$ $<0.05$ or H0 is rejected. Thus the hypothesis proposed is tested by the data so that it can be concluded that the results of learning basic motion on the experimental group using the traditional zondaag mandaag sports game model are higher or more effective than the control group using conventional basic motion learning models. 


\section{Discussion}

The effectiveness test used a research design in the form of a pretest-posttest control group design. The research sample used in this study amounted to 60 students. The experimental class of 30 students and the control class of 30 students were carried out at SD Negeri 064970. The effectiveness of the basic motion learning model based on traditional sports games using the t-test procedure assisted by the IBM SPSS 25 software. The students obtained that the pretest had a mean of 164.10 and a standard deviation of 3.36. After being given treatment of the basic motion learning model based on traditional sports games, the post test results have a mean of 172.73 and a standard deviation of 5.55. This means that quantitatively there is a difference in the average results of the basic movement skills test before and after treatment is given.

The average result of the control class with a sample size of 30 people showed that the mean pre test was 141.03 and a standard deviation of 11.038. After being given a conventional basic motion learning model, the mean post test results are 145.37 and the standard deviation is 6.278. This means that quantitatively there is a difference in the results of the pre-test and post-test before and after being given treatment using a conventional model. To test the effectiveness of the model using the t-test by fulfilling the prerequisite tests for normality and homogeneity. The results of normality testing are seen from the Kolmogorov-Smirnov value, it is known that the sig.i value for the experimental group data is 0.058 and the control group data is 0.092 .

The results of the sig value of the two groups $>\alpha(0.05)$, it can be concluded that the overall data of the research group is normally distributed. Homogeneity is seen by the value of Equal variances assumed and Levene's Test for Equality of Variances, the value of $\mathrm{F}=$ 0.030 is obtained with a sig or p-value $=0.864>0.05$, which means that the population variances of the two groups are the same or homogeneous and meet the requirements for hypothesis testing. From the results of data testing, it is obtained Equal variances assumed and t-test for Equality of Means with a value of $\mathrm{t}=17.877 \mathrm{df}=58(\mathrm{n}-2)$ and sig (2 tailed) or $\mathrm{p}$-value $=0.000<0.05$ or $\mathrm{H} 0$ is rejected. Thus the hypothesis proposed is tested by the data so that it can be concluded that the results of the basic motion of the experimental group using the traditional zondaag mandaag sports game model are higher or more effective than the control group using the conventional model.

The results of research relevant to this model based on research (Veni Elisyah, James Tangkudung, Wahyuningtyas Puspitorini, 2015) show that the basic motion learning model for 40 meter athletic running based on traditional games is effectively applied to elementary school students as evidenced by the $\mathrm{N}$-gain score. the average $\mathrm{N}$-gain score of elementary school students. The experimental class was $79.21 \%$ included in the "effective" category. The limitations of this study were because the teacher had difficulty understanding some models of basic motion learning models of traditional zondaag mandaag sports games carried out by children aged 10-12 years. To overcome this, researchers read mentors from among final semester students who take part in helping researchers. 


\section{Conclusion}

Based on the results and processing of research data and discussion, the research can be concluded as follows: basic motion learning models (locomotor, non-locomotor and manipulative) traditional zondaag mandaag sports games in children aged 10-12 years are effective for improving basic motion learning outcomes. Based on the results of the Equal variances assumed and Levene's Test for Equality of Variances, the value of $F=0.030$ was obtained with a sig or p-value $=0.864>0.05$, which means that the population variances of the two groups are the same or homogeneous. The results of the hypothesis test for Equal variances assumed and t-test for Equality of Means obtained a value of $t=17.877, \mathrm{df}=58$ and sig ( 2 tailed) or p-value $=0.000<0.05$ or $\mathrm{H} 0$ is rejected. The results of locomotor, nonlocomotor and manipulative basic motion of the traditional zondaag mandaag sports game in children aged 10-12 years of the experimental group were higher or more effective than the control group. Thus the proposed hypothesis is tested by the data so that it can be concluded that the results of the basic motion of the experimental group using the traditional sports development model are higher or more effective than the control group using the conventional model.

\section{References}

Egan, C. A., Webster, C. A., Stewart, G. L., Weaver, R. G., Russ, L. B., Brian, A., \& Stodden, D. F. (2019). Case Study of a Health Optimizing Physical Education-Based Comprehensive School Physical Activity Program. Evaluation and Program Planning, 72(October 2018), 106-117. https://doi.org/10.1016/j.evalprogplan.2018.10.006

Figueroa, R., \& An, R. (2016). Motor Skill Competence and Physical Activity in Preschoolers: Maternal and Child Health Journal, 2009. https://doi.org/10.1007/s10995-016-2102-1

Gallahue, David L. (2006) Understanding Motor. Development Basic Children, Adolesent, Adults. New York: Mc Graw Hill, Six Edition.

Kain, J., Concha, F., Salazar, G., Leyton, B., Rodríguez, P., Ceballos, X., \& Vio, F. (2009). Prevención de Obesidad en Preescolares y Escolares de Escuelas Municipales de Una Comuna de Santiago de Chile: proyecto piloto 2006. ARCHIVOS LATINOAMERICANOS DE NUTRICION, 59(4), 139-146.

Klingberg, B., Schranz, N., Barnett, L. M., \& Booth, V. (2018). The Feasibility of Fundamental Movement Skill Assessments For Pre-School Aged Children. Journal of Sports Sciences, 00(00), 1-9. https://doi.org/10.1080/02640414.2018.1504603

Lin, S., \& Yang, S. (2015). The Development of Fundamental Movement Skills by Children Aged Six to Nine. Universal Journal of Educational Research 3(12):, 3(12), 1024-1027. https://doi.org/10.13189/ujer.2015.031211

Monsalves-alvarez, M., Sepulveda, M. C., Zapata-lamana, R., \& Rosales-soto, G. (2015). Motor Skills and Nutritional Status Outcomes From a Physical Activity Intervention in Short Breaks on Preschool Childrens Conducted by Their Educators: a Pilot Study. Article in Nutricion Hospitalaria: Organo Oficial de La Sociedad Espanola de Nutricion Parenteral y Entera, 32(4), :1575-1580. https://doi.org/10.3305/nh.2015.32.4.9514

Nazario \& Vieira. (2013). Sport Context and The Motor Development of Children. Revista Brasileira de Cineantropometria e Desempenho Humano, 16 (1)(March), 86-95.

Piliang, F And Asnewastri. (2020). The Effect of Project Based Learning Model in the Group Investigation in Learning Strategy on Social Attitude Student Subject in USI 
Pematangsiantar. Budapest International Research and Critics Institute-Journal (BIRCIJournal). P. 1599-1605.

Rahman, Z. A., Kamal, A. A., Nor, M. A. M., Latif, R. A., Education, F., \& Mara, U. T. (2020). The Effectiveness of Teaching Games for Understanding to Promote Enjoyment in Teaching Games of Physical Education Lesson. 9(1), 23-32. https://doi.org/10.37134/jsspj.vol9.1.4.2020

Rodrigues, D., Leal, E., José, A., \& Barela, A. (2015). Proficiency of Fundamental Motor Skills in Children of A Public School in the City of São Paulo. Brazilian Journal of Motor Behavior, 9(1), 1-9. https://doi.org/http://socibracom.com/bjmb/index.php/bjmb/article/view/53/64

Simorangkir, F. And Sembiring, R. (2018). Effectiveness of Helped Mathematical Learning Media of Lectora Inspire on The Number Sense Ability of Fifth Grade Students of Elementary School in Substrate Materials. Budapest International Research and Critics Institute-Journal (BIRCI-Journal). P. 352-358

Sugiyono. (2017). Metode Penelitian Pendidikan: Pendekatan Kuantitatif, Kualitatif, dan R\&D. Alfabeta.

Tucker, P. (2008). Early Childhood Research Quarterly The Physical Activity levels of preschool-aged Children: A Systematic Review. Early Childhood Research Quarterly 23, 23, 547-558. https://doi.org/10.1016/j.ecresq.2008.08.005

Veni Elisyah, James Tangkudung, Wahyuningtyas Puspitorini, P. C. K. (2015). Journal of Physical Education, Sport, Health and Recreations. Journal of Physical Education, Sport, Health and Recreation, 4(2), 102-108. http://journal.unnes.ac.id/sju/index.php/peshr

Yani, I. (2015). Stimulasi Perkembangan Anak Melalui Permainan Tradisional Suku Batak Toba. Jurnal Ilmiah VISI PGTK PAUD Dan DIKMAS, 12(2), 89-98. 